\title{
A CHEMICAL INVESTIGATION OF THE DEFECTS OF MYELINATION IN PHENYLKETONURIA
}

\author{
L. CROME, V. TYMMS, AND L. I. WOOLF' \\ From the Fountain Hospital, London, and the Department of the Regius Professor \\ of Medicine, Radcliffe Infirmary, Oxford
}

The relationship between the metabolic abnormality and the mental deficiency characteristic of phenylketonuria has been the subject of speculation and experiment since the condition was first discovered. An 'intoxication' has been postulated (Woolf and Vulliamy, 1951) and it has been shown that the functioning of a number of different enzymes present in the brain is affected. However, at least in some cases, the actual morphology of the brain appears to be altered and the occurrence of these neural lesions must be fitted into the overall picture.

The suggestion that the mental and neurological effects of phenylketonuria were due to intoxication by phenylalanine or its metabolites appears to have been confirmed by the success of a diet low in phenylalanine in preventing or ameliorating, in some cases, the mental deficiency and neurological abnormalities (Woolf and Vulliamy, 1951; Bickel, Gerrard, and Hickmans, 1953; Woolf, Griffiths, and Moncrieff, 1955; Armstrong and Tyler, 1955; Blainey and Gulliford, 1956; Horner and Streamer, 1956; Low, Bosma, and Armstrong, 1957; Woolf, Griffiths, Moncrieff, Coates, and Dillistone, 1958; Brimblecombe, Stoneman, and Maliphant, 1959; Murphy, 1959).

The concentrations in the blood of noradrenaline and 5-hydroxytryptamine are reduced in phenylketonuria (Weil-Malherbe, 1955; Pare, Sandler, and Stacey, 1957, 1959). The enzymes DOPA-decarboxylase, 5-hydroxytryptophan decarboxylase, and glutamic acid decarboxylase are partly inhibited by some of the abnormal metabolites of phenylalanine present in phenylketonurics, and it has been suggested that the mental abnormalities are due to the consequent partial inhibition of synaptic transmission (Fellman, 1956; Davison and Sandler, 1958; Sandler, Davies, and Rimington, 1959; Hanson, 1959; Tashian, 1961).

The question of the occurrence of neural lesions in the brains of phenylketonurics is particularly important. Not only might such lesions help to explain the main clinical features of the condition, but their absence or presence in a particular case

${ }^{1}$ Member of the Medical Research Council's external scientific staff. would control, to a large extent, the reversibility of the condition and the outcome of treatment. Since treatment with a diet low in phenylalanine is most successful in cases treated from early infancy, and there is evidence that the mental status of untreated phenylketonurics deteriorates as they get older, the time of occurrence of any neural lesions is important.

Alvord, Stevenson, Vogel, and Engle (1950), in necropsies on five cases of phenylketonuria, found poor myelinization in various parts of the central nervous system, particularly in their younger patients. They suggested that myelinization was 'delayed' in phenylketonuria, the lack of myelin eventually being made good, and that the mental deficiency was partly due to this. Poser and van Bogaert (1959) found multiple areas of altered myelination and fibrillary gliosis. They suggest that the underlying pathogenetic defect in phenylketonuria may be a disturbance of the glial cell-myelin sheath relationship. However they found no evidence of active destruction of myelin and regard phenylketonuria as a dysmyelinating disease rather than a demyelinating one.

Crome and Pare (1960) have recently reviewed the neuropathological findings in phenylketonuria on the basis of 20 previously recorded necropsies and four of their own. The most consistent change is reduction in weight of the brains and this may be accompanied by ventricular dilatation. Many of the smaller brains display diffuse fibrous gliosis (scarring) of the white matter and the total volume of the white matter is reduced. In about one-third of the cases, poor or 'delayed' myelination was noted on the basis of poor uptake of stains, such as ironhaematoxylin, by the white matter. However there is little apparent change in the shape or staining properties of the remaining individual myelin fibres.

It is noteworthy that widespread demyelination is present in the central nervous system of some of the older patients (Benda, 1952). Jervis (1954) reported an adult phenylketonuric who developed Schilder's disease; the oldest phenylketonuric patient reported below (Case 4) also showed changes in the white matter characteristic of Schilder's disease. 
It seemed possible that these histological observations could be extended by chemical analysis of the white matter for cerebrosides, a group of closely related substances occurring only in myelin. This was done for four phenylketonurics of different ages and for age-matched controls and the results obtained, as well as the water content and the cholesterol content of the white matter, are reported below.

\section{MATERIAL}

Slices of the frontal lobes of the brains of four phenylketonurics and five controls were examined (Table I). The brains had been fixed in neutral formol-saline soon after death and kept in the fixative. Of the five control subjects, two had been mongolian idiots, one had had muscular dystrophy, and two had been normal. In all five no abnormality of the white matter was detected. Details of the clinical history and pathology of the phenylketonurics have been published (Crome and Pare, 1960; Crome, 1962) and are summarized in Table I. Case 4 illustrates a special problem, presenting an association of phenylketonuria with leucodystrophy (Schilder's disease).

CEREBROSIDE STANDARD The white matter of one-half of a fresh ox brain was homogenized with acetone and the cerebrosides extracted from the dried powder by the tetralin method of Page (1930). The crude cerebroside precipitated from the tetralin solution was washed,

TABLE I

SUMMARY OF CLINICAL AND PATHOLOGICAL FEATURES OF CASES EXAMINED

$\begin{array}{llll}\text { Case No. Sex } & \text { Age Main Clinical Features } & \text { Main Pathological Features } \\ & & \text { Time } & \text { (months) }\end{array}$

\begin{tabular}{|c|c|c|c|c|c|}
\hline $\begin{array}{l}\text { 1 }(\text { (J.P.) } \\
\text { PM } 2 / 58\end{array}$ & $\mathbf{M}$ & 2 yr. & $\begin{array}{l}\text { Slowness of development apparent at } 9 \mathrm{mth} \text {. } \\
\text { Phenylketonuria diagnosed at } 13 \mathrm{mth} \text {. } \\
\text { Phenylalanine-free diet resulted in some } \\
\text { doubtful improvement. I.Q. } 23 . \\
\text { Head circumference at } 19 \mathrm{mth} .41 .8 \mathrm{~cm} \text {. } \\
\text { (normal } 48.8 \text { with S.D. } \pm 1 \cdot 1 \text { ). }\end{array}$ & $\begin{array}{l}\text { Brain weight } 737 \mathrm{~g} \text {. (average normal for age } \\
1,064 \mathrm{~g} .) \text {. Diffuse fibrous gliosis of centrum } \\
\text { semiovale and small focus of post-necrotic } \\
\text { scarring in cerebellum. }\end{array}$ & 37 \\
\hline $\begin{array}{l}2 \text { (B.N.) } \\
\text { PM } 24 / 57\end{array}$ & $\mathbf{M}$ & 20 mth. & $\begin{array}{l}\text { Retarded development since early infancy. } \\
\text { Grand mal since } 1 \text { yr. Probably deaf. } \\
\text { Phenylketonuria diagnosed at } 13 \mathrm{mth} \text {. } \\
\text { Head circumference at } 15 \mathrm{mth} .43 .9 \mathrm{~cm} \text {., } \\
\text { normal being } 48.8 \text { with S.D. } \pm 1 \cdot 1 . \\
\text { Iron-deficiency anaemia. I.Q. } 20 . \\
\text { Tremor of hands. Hypotonia. }\end{array}$ & $\begin{array}{l}\text { Brain weight } 871 \mathrm{~g} \text {. (average normal for age } \\
1,050 \mathrm{~g} \text {.). Ventricles moderately dilated. } \\
\text { Slight reduction in thickness of corpus callosum } \\
\text { and centrum semiovale. Generalized diffuse } \\
\text { fibrous gliosis of cerebral and cerebellar white } \\
\text { matter. }\end{array}$ & 38 \\
\hline $\begin{array}{l}3 \text { (H.H.) } \\
\text { PM } 10 / 58\end{array}$ & $\mathbf{M}$ & $20 \mathrm{mth}$. & $\begin{array}{l}\text { Retarded development since early infancy. } \\
\text { Phenylketonuria diagnosed at } 10 \mathrm{mth} \text {. } \\
\text { Head circumference at } 1 \mathrm{yr} .44 \cdot 7 \mathrm{~cm} . \\
\text { normal being } 47 \cdot 1 \mathrm{~cm} \text {. with S.D. } \pm 1 \cdot 3 \text {. } \\
\text { Slight hypotonia. Imbecile level of intelligence. }\end{array}$ & $\begin{array}{l}\text { Brain weight } 870 \mathrm{~g} \text {. (average normal for age } \\
1,050 \mathrm{~g} . \text {.). Slight to moderate fibrous gliosis of } \\
\text { white matter in frontal and temporal lobes. } \\
\text { Possible pallor of myelin staining in temporal } \\
\text { lobes. }\end{array}$ & 34 \\
\hline $\begin{array}{l}4 \text { (C.B.) } \\
\text { PM } 23 / 59\end{array}$ & $\mathbf{F}$ & $16 \mathrm{yr}$. & $\begin{array}{l}\text { Blue asphyxia at birth. Severe mental and } \\
\text { physical retardation since early infancy. } \\
\text { Petit mal and grand mal seizures. } \\
\text { Phenylketonuria diagnosed at } 6 \mathrm{yr} \text {. } \\
\text { Head circumference at } 6 \mathrm{yr} .47 .7 \mathrm{~cm} . \text {, } \\
\text { normal being } 50.8 \mathrm{~cm} \text {. with S.D. } \pm 1 \cdot 4 \text {. } \\
\text { Mentally an idiot. Spasticity of legs after } \\
\text { age } 10 \text {. }\end{array}$ & $\begin{array}{l}\text { Brain weight } 800 \mathrm{~g} \text {. (average normal for age } \\
1,350 \mathrm{~g} . \text { ). Extensive demyelination of cerebral } \\
\text { white matter as in leucodystrophy (Schilder's } \\
\text { disease). Posterior half of corpus callosum thin. } \\
\text { Vacuolation of white matter in non-demyelinated } \\
\text { areas. }\end{array}$ & 17 \\
\hline $\begin{array}{l}5 \text { (J.P.H.) } \\
\text { PM } 28 / 55\end{array}$ & $\mathbf{F}$ & $20 \mathrm{mth}$. & $\begin{array}{l}\text { Mongolism. Good physique. Bilateral } \\
\text { syndactyly of } 4 \text { th and } 5 \text { th toes. } \\
\text { Mental level imbecile. }\end{array}$ & $\begin{array}{l}\text { Brain weight } 740 \mathrm{~g} \text {. (average normal for age } \\
1,050 \mathrm{~g} . \text {.) No histological abnormality of } \\
\text { neural tissue. Anomaly of main veins entering } \\
\text { heart. Atrial septal defect of ostium secundum } \\
\text { type. }\end{array}$ & 67 \\
\hline $\begin{array}{ll}6 & (\mathrm{~S} .) \\
\text { B } & 117 / 57\end{array}$ & $\mathbf{M}$ & $16 \mathrm{yr}$. & $\begin{array}{l}\text { Progressive muscular dystrophy since } 2 \text { yr. } \\
\text { Severe scoliosis. Good intelligence. }\end{array}$ & $\begin{array}{l}\text { Brain weight } 1,588 \mathrm{~g} . \text { No histological } \\
\text { abnormality of neural tissue. Typical histo- } \\
\text { logical changes of muscle. }\end{array}$ & 45 \\
\hline $\begin{array}{l}7 \text { (A.G.L.) } \\
\text { PM } 3 / 55\end{array}$ & $\mathbf{M}$ & $4 \mathrm{yr}$. & $\begin{array}{l}\text { Child slightly premature, } 5 \mathrm{lb} \text {. at birth. } \\
\text { Mongolism and cleft palate. } \\
\text { Mentally an idiot. }\end{array}$ & $\begin{array}{l}\text { Brain weight } 1,330 \mathrm{~g} . \text { No histological } \\
\text { abnormality of neural tissue. } \\
\text { Renal necrosis. }\end{array}$ & 73 \\
\hline $\begin{array}{l}8 \text { (P.C.) } \\
\text { B } 122 / 57\end{array}$ & $\mathbf{F}$ & 1 yr. & $\begin{array}{l}\text { Healthy child save for 'asthmatic' } \\
\text { attacks during last month of life. } \\
\text { Terminal asphyxia. }\end{array}$ & $\begin{array}{l}\text { Brain weight } 1,204 \mathrm{~g} . \text { No histological } \\
\text { abnormality of neural tissue. } \\
\text { Pulmonary collapse and emphysema. }\end{array}$ & 44 \\
\hline $\begin{array}{lr}9 & \text { (S.S.) } \\
\text { B } 120 / 59\end{array}$ & $\mathbf{M}$ & $27 \mathrm{mth}$. & $\begin{array}{l}\text { Healthy child with terminal appendicitis } \\
\text { followed by peritonitis. }\end{array}$ & $\begin{array}{l}\text { Brain weight } 1,064 \mathrm{~g} \text {. (average normal for age } \\
1,141 \mathrm{~g} .) \text {. No histological abnormality of } \\
\text { neural tissue. }\end{array}$ & 40 \\
\hline \multicolumn{6}{|c|}{1 Length of storage of brain in formol saline. } \\
\hline
\end{tabular}


first with tetralin-acetone mixture and then with acetone, and dried and dissolved in chloroform methanol $(2: 1)$. The solution was passed through a column of alumina to remove phosphatides (Klenk and Leupold, 1944), followed by a column of Florisil to remove gangliosides, residual phosphatides, and other impurities, and finally through a column of mixed weakly basic anion-exchange resin (Amberlite IR 45, hydroxide form, finely ground) and strongly acidic cation-exchange resin (Amberlite IR 120, hydrogen form, finely ground) (cf. Radin, Lavin, and Brown, 1955). The three columns had been thoroughly washed previously with methanol and chloroform methanol mixture. The final effluent was evaporated to dryness in a stream of nitrogen and the residue crystallized twice from chloroform ethanol (2:1) (Page, 1930). The crystals were dried in vacuo over $\mathrm{P}_{2} \mathrm{O}_{5}, \mathrm{KOH}$, and paraffin wax.

The material formed pure white needles, melting with decomposition at $151^{\circ} \mathrm{C}$. (initial sintering) to $182^{\circ} \mathrm{C}$. (final melting) (temperatures uncorrected).

Analyses by Weiler and Strauss were as follows: Found, carbon $68.8 \%$, hydrogen $11.4 \%$, nitrogen $2.05 \%$, phosphorus $0.07 \%$. Kerasin, $\mathrm{C}_{48} \mathrm{H}_{94} \mathrm{NO}_{8}$, requires carbon $71 \%$, hydrogen $11.6 \%$, nitrogen $1.72 \%$. Galactose (obtained by the orcinol method, see below), found $21.9 \%$ (theoretical 22.04\%).

\section{METHODS}

A slice about $3 \mathrm{~mm}$. thick through the frontal lobe of each brain was taken and the grey matter dissected off. In Case 4 , in addition to the slice through the frontal lobe, portions of white matter from areas undergoing active demyelination and adjoining portions of 'normal' white matter, where no sudanophilic demyelination could be detected, were dissected out. The white matter was washed in running water for 36 hours, then carefully blotted dry, finely chopped, and mixed. A portion was weighed and dried to constant weight at $70^{\circ} \mathrm{C}$., giving the water content. A second portion was weighed then homogenized (M.S.E. homogenizer, full speed, 2 min.) with a mixture of chloroform and methanol $(2: 1)$, allowing $20 \mathrm{ml}$. for each gram of tissue. The mixture was filtered and the residue thoroughly washed with chloroform methanol.

The filtrate and washings, containing the total lipids of the white matter, were shaken with a $0 \cdot 38 \%$ solution of magnesium chloride in water, allowing (25-w) ml. per $100 \mathrm{ml}$. of organic phase (where $\mathrm{w}=$ the water contributed by the material homogenized). The phases were separated in the centrifuge, the upper layer was removed taking care not to disturb the material at the interface, and the organic phase washed twice with about one-third its volume of a $0 \cdot 17 \%$ solution of magnesium chloride in water-methanol-chloroform mixture $(47: 48: 3)$, shaking each time and separating the layers in the centrifuge as before (cf. Svennerholm, 1956; Folch, Lees, and Sloane Stanley, 1957).

The organic phase and the interfacial material was made up to its original volume with methanol. A $10 \mathrm{ml}$. portion was passed through a column of Florisil (60 mesh), $1 \mathrm{~cm}$. diameter by $8 \mathrm{~cm}$. long, and washed through with chloroform methanol $(2: 1)$, being finally made up to $25 \mathrm{ml}$. (cf. Radin et al., 1955). This constituted the purified brain extract.

Duplicate $2.5 \mathrm{ml}$. portions of this final solution were evaporated to dryness in test tubes in a stream of nitrogen. Syrupy phosphoric acid $(2 \mathrm{ml}$.) was added to each tube which was then heated to $100^{\circ} \mathrm{C}$. for $10 \mathrm{~min}$., and swirled to disperse the lipids (Radin et al., 1955). After cooling in ice water, $5 \mathrm{ml}$. of a $\mathbf{0} \cdot 14$ solution of orcinol in sulphuric acid-water mixture $(2: 1 \mathrm{v} / \mathrm{v})$ was added and well mixed with a glass rod. The tubes were heated at $80^{\circ} \mathrm{C}$. for 20 min., cooled, centrifuged, and the colour in the clear lower layer read in a Unicam ' 600 ' spectrophotometer at $520 \mathrm{~m} \mu$ (cf. Radin et al., 1955; Svennerholm, 1956). Known amounts of pure cerebroside, dissolved in chloroform methanol $(2: 1)$, and of galactose in water were treated similarly with each batch of purified brain extracts. In a separate experiment the effect was found of adding various amounts of cholesterol to the standard solution of pure cerebroside.

Free and total cholesterol were determined in the purified brain extracts by Leffler's (1960) modification of the method of Zak (1957), using pure cholesterol or cholesterol stearate as standards. Beer's law was obeyed and the free and esterified cholesterol gave the same molar colour yield. The content of cholesterol ester in the brain extracts was calculated by difference.

\section{RESULTS}

After dispersion in phosphoric acid and reaction with orcinol reagent, both the cerebroside standard and galactose gave clear red-brown solutions, indistinguishable in colour, with a single absorption peak

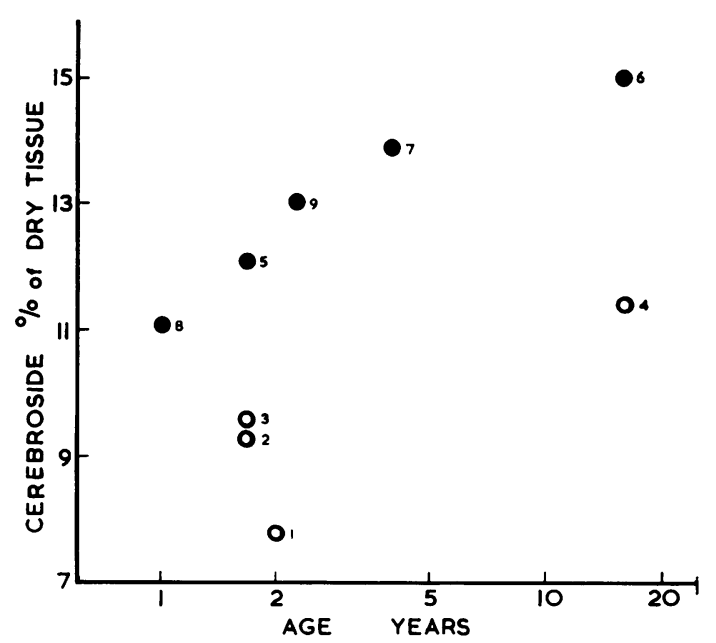

FIG. 1. Cerebroside content of white matter plotted against age (log scale).

normal controls 0 phenylketonurics

The case number is shown beside each point. 
TABLE II

RESULTS OF CHEMICAL INVESTIGATION OF WHITE MATTER

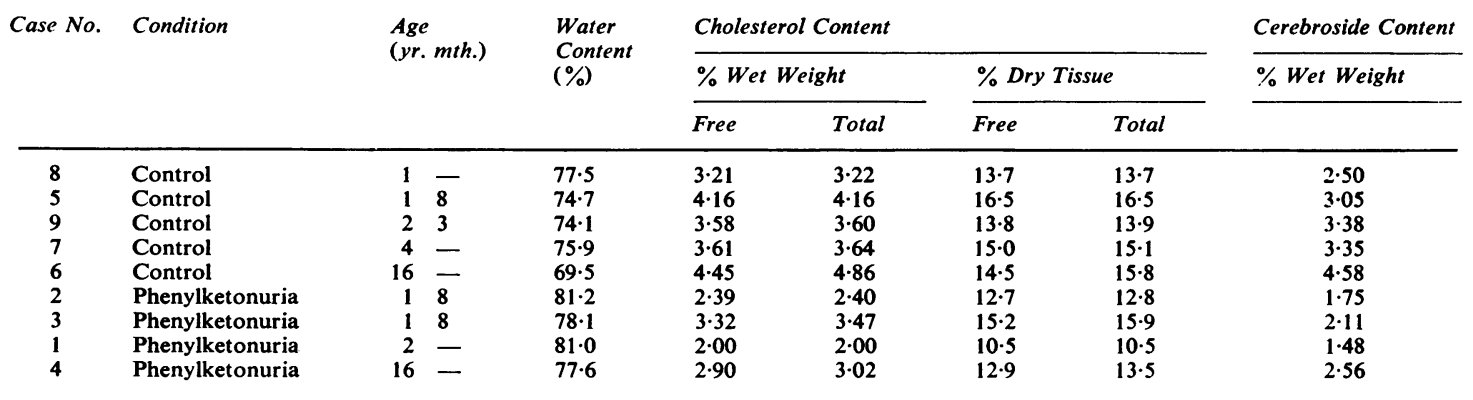

at $520 \mathrm{~m} \mu$ and obeying Beer's law. Weight for weight, the cerebroside gave $21.9 \%$ of the optical density given by galactose. The effect of adding cholesterol to the cerebroside was to produce, in the final solution, a black insoluble substance that floated on the surface after centrifuging; neither the colour nor the optical density of the bulk of the solution was affected.

The cerebroside content of the white matter of the nine brains, expressed as a percentage of the dry tissue, is shown in Fig. 1. The other results are given in Table II. The results for the 'normal' and demyelinating regions of white matter in Case 4 are presented elsewhere (Crome, 1962).

\section{DISCUSSION}

Fixation in formalin destroys the phospholipids of brain in a few months, but the galactolipids and cholesterol are unaffected (Weil, 1929; Brante, 1949). There is also a rise in the water content of brain on formalin fixation (Weil, 1929), but this is too small to account for the differences between phenylketonuric and normal brains found in the present investigation. Since the normal and phenylketonuric brains were treated alike, it is a reasonable conclusion that the differences found in contents of water, cerebrosides, and cholesterol were not artefacts.

The high water content of the white matter of the brain in phenylketonuria is in agreement with the finding of small vacuoles in the white matter (Benda, 1952; Crome and Pare, 1960). It is consistent with the suggestion that the number of myelinated fibres per unit of volume of brain is reduced in phenylketonuria. This reduction in number of myelinated fibres may well account for much of the mental and neurological deterioration characteristic of the condition. The four phenylketonurics reported here were low-grade cases. We have no evidence that similar changes occur in the small proportion of cases of I.Q. over 50.

Cerebrosides, as estimated here, are a complex mixture of closely related substances. All contain galactose joined by a glycoside linkage to sphingosine or dihydrosphingosine combined with one of a small number of long-chain fatty acids. In some of the substances (sulphatides) the galactose is sulphated and in others it is linked to a water-soluble amine. These substances are so similar that they can all be estimated together by the orcinol method. In effect it is the galactose in the molecule which is being estimated, and this varies little in amount from one molecular species to another. All these substances occur in the myelin sheath of medullated nerve fibres and only in traces in other tissues, though related compounds occur in the spleen, etc. in Gaucher's disease. Cerebrosides form one of the most characteristic components of the myelin sheath and estimation of the total cerebrosides in the white matter can be regarded as a measure of the amount of myelin present.

Cholesterol in the central nervous system occurs mainly in the myelin of the white matter. Virtually all the cholesterol in myelin is unesterified and the occurrence of appreciable amounts of cholesterol esters reflects active destruction of myelin (Johnson, McNabb, and Rossiter, 1949; Cumings, 1959). The low values for esterified cholesterol in the white matter found in three out of the four phenylketonurics (Table II) is evidence that active demyelination was not prominent in these cases; in the fourth case active demyelination evidently occurred mainly in restricted areas of the white matter (see Table $I$ in Crome, 1962).

The content of cerebrosides and free cholesterol in the phenylketonuric brain is much lower than in the normal, and this is clear evidence of a lack of myelin in phenylketonuria. This is so even in Cases 1 and 2 where histological examination did not reveal 
defective myelination. The variation from case to case in the content of myelin lipids in the brains of phenylketonurics, showing little correlation with age, is in marked contrast to the findings in normal brains (Fig. 1). This is not unexpected in a disease varying in severity. Our results are not in agreement with the suggestion of Alvord et al. (1950) that myelination is only delayed in phenylketonuria, and occurs at a later age than in the normal brain.

It seems probable that in phenylketonuria the abnormal concentrations of phenylalanine and its metabolites in the body fluids hinder the laying down of myelin, as suggested by Alvord et al. (1950) and Poser and van Bogaert (1959). Entire fibres in the white matter are removed; at present there is no evidence as to whether this precedes myelination and explains the lack of myelin, or whether the function of the oligodendroglial cells is interfered with and the resulting non-myelinated or poorly myelinated fibre later destroyed. Either explanation would fit the clinical observations that most of the damage to the functioning of the nervous system in phenylketonuria occurs during the first few months of life and that this damage is only partly reversible by dietary treatment instituted later (Woolf et al., 1958). That it is reversible at all suggests that, in addition to their effect on myelination, phenylalanine and its metabolites interfere with some function of the brain not directly related to the structure of the white matter. The effects of a low phenylalanine diet are most satisfactory in cases where relatively little mental deterioration has occurred (Woolf et al., 1958); these are the cases where we have no information on myelination but where we would expect least damage to the white matter.

In Case 4, the oldest of the four phenylketonurics reported here, areas of active demyelination occurred in the white matter (Crome, 1962). In these there was a further marked fall in the dry weight and a moderate decrease in the percentage of cerebroside and free cholesterol in the dry matter, as well as a marked rise in cholesterol ester. However sudanophilic demyelination is not usually observed in phenylketonuria and actual destruction of myelin sheaths, if it occurs at all, is very slow in the majority of cases. Such gradual demyelination would be difficult to detect either histologically or chemically.

The following hypothesis fits the clinical and biochemical findings. The toxic substances in the body fluids cause a depression of neurone function, some neurones succumbing completely. The axons of those that succumb early never become well myelinated. Where neurone death occurs later in life it leads to demyelination, but on so localized a scale, if few neurones are involved at any one time, as to make it difficult to detect. The restoration of full function to the surviving neurones, when a low phenylalanine diet is started, accounts for the resulting clinical improvement; the irremediable damage is partly accounted for by the loss of those neurones and their axons which were destroyed before treatment.

\section{SUMMARY}

The white matter of the brains of four phenylketonurics and five controls has been analysed chemically. The water content in all four phenylketonurics was high compared with that of the controls. The cerebroside content of the dry matter was markedly lower in the phenylketonurics than in the controls, and the cholesterol content was also lower. This is in agreement with the view that the laying down of myelin appears to be hindered in phenylketonuria, but a gradual demyelination is not excluded. This is discussed in relation to the clinical and biochemical features of phenylketonuria. In the oldest case in the present series there were, in the white matter, regions of active demyelination where the water content was still higher, and the cerebroside and free cholesterol content somewhat lower, than in adjoining regions; in these regions of active demyelination there was an accumulation of cholesterol ester.

We wish to thank Sir George Pickering for his helpful discussion and criticism of this paper. Miss H. R. Bloxam, Mr. M. G. Day, and Miss S. Mallen gave expert technical assistance. The earlier stages of the investigation were carried out at the Medical Research Council's Population Genetics Research Unit, Oxford.

\section{REFERENCES}

Alvord, E. C. Jr., Stevenson, L. D., Vogel, F. S., and Engle, R. L. (1950). J. Neuropath. exp. Neurol., 9, 298.

Armstrong, M. D., and Tyler, F. H. (1955). J. clin. Invest., 34, 565.

Benda, C. E. (1952). Developmental Disorders of Mentation and Cerebral Palsies, p. 451. Grune \& Stratton, New York.

Bickel, H., Gerrard, J., and Hickmans, E. M. (1953). Lancet, 2, 812.

Blainey, J. D., and Gulliford, R. (1956). Arch. Dis. Childh., 31, 452

Brante, G. (1949). Acta physiol. scand., 18, Suppl. 63.

Brimblecombe, F. S. W., Stoneman, M. E. R., and Maliphant, R. (1959). Lancet, 1, 609 .

Crome, L. (1962). J. Neurol. Neurosurg. Psychiat., 25, 149.

$\longrightarrow$, and Pare, C. M. B. (1960). J. ment. Sci., 106, 862.

Cumings, J. N. (1959). In Biochemical Aspects of Neurological Disorders, p. 188. Ed. Cumings, J. N., and Kremer, M. Blackwell, Oxford.

Davison, A. M., and Sandler, M. (1958). Nature, Lond., 181, 186.

Fellman, J. H. (1956). Proc. soc. exp. Biol. (N.Y.), 93, 413.

Folch, J., Lees, M., and Sloane Stanley, G. H. (1957). J. biol. Chem., 226, 497.

Hanson, A. (1959). Acta chem. scand., 13, 1366.

Horner, F. A., and Streamer, C. W. (1956). J. Amer. med. Ass., 161, 1628

Jervis, G. A. (1954). Res. Publ. Ass. Res. nerv. ment. Dis., 33, 259.

Johnson, A. C., McNabb, A. R., and Rossiter, R. J. (1949). Biochem. $J ., 45,500$.

Klenk, E., and Leupold, F. (1944). Hoppe-Seylers Z. physiol. Chem., 281, 208. 
Leffler, H. H. In Sunderman, F. W., and Sunderman, F. W. Jr. (1960). Lipids and the Steroid Hormones in Clinical Medicine, p. 18. Lippincott, Philadelphia.

Low, N. L., Bosma, J. F., and Armstrong, M. D. (1957). A.M.A. Arch. Neurol. Psychiat., 77, 359.

Murphy, D. (1959). Irish J. med. Sci., p. 425.

Page, I. H. (1930). Biochem. Z., 219, 161.

Pare, C. M. B., Sandler, M., and Stacey, R. S. (1957). Lancet, 1, 551. - . . (1959). Arch. Dis. Childh., 34, 422.

Poser, C. M., and Bogaert, L. van (1959). Brain, 82, 1.

Radin, N. S., Lavin, F. B., and Brown, J. R. (1955). J. biol. Chem., $217,789$.

Sandler, M., Davies, A., and Rimington, C. (1959). Lancet, 2, 318.
Svennerholm, L. (1956). J. Neurochem., 1, 42.

Tashian, R. E. (1961). Metabolism., 10, 393.

Weil, A. (1929). J. biol. Chem., 83, 601.

Weil-Malherbe, H. (1955). In Biochemistry of the Developing Nervous System, p. 458. Proceedings of the First International Neurochemical Symposium, Oxford, 1954, ed. H. Waelsch. Academic Press, New York.

Woolf, L. I., Griffiths, R., and Moncrieff, A. (1955). Brit. med. J., 1, 57. Childh., 33, 31.

-, and Vulliamy, D. G. (1951). Ibid., 26, 487.

Zak, B. (1957). Amer. J. clin. Path., 27, 583. 